\title{
The Existence of Jaranan Pogogan in Sugihwaras, Prambon, Nganjuk,
}

\section{Indonesia}

Eko Gatut Febrianto', Djono $^{2}$ and Sudiyanto ${ }^{3}$

${ }^{1}$ Student of Magister Program in Department of Historical Education

${ }^{2,3}$ Lecture of Sebelas Maret University

\section{Abstract}

Traditional art is a regional art as a part of national culture th must be preserved. Jaranan Pogogan is a traditional dance fro: Nganjuk. Jaranan Pogogan has been developing since 1950 bl gradually became extinct in the 1980's. The aim of the author is to raise the theme that Jaranan Pogogan can be preserved by the younger generation, with the theme of traditional arts expected to raise student interest in learning history. The research method used in this paper is qualitative and literature study data for data collection. The data obtained in this study passes the data analysis procedure that occurs simultaneously, namely data reduction, data presentation, and conclusion or data verification. The data generated in this study shows the relationship between the values of Jaranan Pogogan which is original of Nganjuk culture as a historical learning for the next generation that upholds the noble values, local wisdom and manners.
Keywords

Avalues of Art; Jaranan

Pogogan; Historical

Learning

(3)

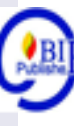

\section{Introduction}

The characteristic form of a society in a region has a diversity of media to express culture. Culture comes from the Sanskrit word buddhayah, which is the plural form of buddhi which means "mind" or "reason". Thus culture can be interpreted as relevant matters with reason and is the result of copyright, intention. Culture as a functional need in society continues gradually and is passed down from one previous generation to the next. Cultural inheritance can be through an educational process, not because of heredity or genes, but adapted to the development and conditions that exist in groups of conservation communities. More and more demands must be met, encouraging people to adopt cultural influences that are deemed appropriate to meet the needs of the community. Koentjaraningrat believes that a culture can take three forms, namely 1) the form of culture as a complex of ideas, ideas, values, norms, rules and so on; 2 ) the form of culture as a complex of activities and patterned actions from humans in society; 3 ) forms of culture as objects created by humans.

One part of culture is in the form of art, art in relation to culture, choosing several media including music, fine arts, dance, etc. Dance itself is one part of art that combines fine arts as an implementation of the expression of the motion of the perpetrators called dancers. The art of music becomes an inseparable part of dance performance, which has a role as a dancer's accompaniment in performing dance moves. Judging from its form, dance is an art that explores the beauty of human body movements that move, in harmony with the rhythm of music, rhythmic and soulful or can give meaning. Dance is the beauty of the forms of human limbs that move, in rhythm and in harmony.

One form of artistic expression that developed in Indonesia is dance. Each tribe in Indonesia has a specific dance that develops in each tribe. Dance or dance is an expression of the soul of human art expressed through beautiful movements and rhythms that give satisfaction to others. The beautiful movements and rhythm are actually the radiance of the human soul and the soul is usually in the form of reason / ideas, will and emotions.

Traditional in the past time were grouped into Hinduism group. Public community, in the background of monotheism conception, believing in divine revelation think traditional faiths as 
dynamism, animism and superstition. This stigma has faded the virtues and impoverished the truths of traditional faith community, even once in a while has shown various intolerant acts. (Ndona, 2019)

Traditional art is a form of regional art as one part of national culture that must be preserved. Nganjuk Regency is a Regency located in East Java which has an ethnic Javanese "Kulonan". Nganjuk Regency is famous for Tayub art, but that does not mean it is possible for other arts to develop in Nganjuk Regency. Nganjuk has many art creations ranging from music, drama and dance. One of the arts that is quite much in demand until now is Jaranan dance. Jaranan art in each region has its own characteristics which are certainly different both in appearance and property used. In general there are five types of jaranan arts found in East Java, namely Jaranan Jawa, Jaranan Buto / Turanggayaksa, Jaranan Sentherewe, Jaranan Pegon, and Jaranan Breng. Jaranan Pogogan is a typical jaranan art from Nganjuk district.

Art grows and develops in a civilization because basically humans need the satisfaction of feelings of beautiful things, in addition to other material needs. Jaranan Pogogan as one of the traditional arts rich in values and morals is actually very relevant to be used as a value education. Muhammad Ali (2007: 2) Opinion that the education of values to shape the whole human personality through teaching and learning activities. Jaranan Pogogan for the community in Nganjuk Regency is played in several activities such as; Customary ceremony (Nyadran), village cleansing, wedding / circumcision reception, and several other entertainment events. In Jaranan Pogogan's art, the values of community life are contained; a) educational values b) religious / sacred values, c) customs / traditions values, d) creative values, e) social values and f) commercial values.

\section{Research Method}

The purpose of this study, firstly, is to provide new insights on the strategy and development of traditional arts amid information technology determination. Secondly, finding alternative models to protect traditional arts as the cultural identity of supporting communities, but remain synergistic with the demands of globalization. To support the objectives of the activity, a field research was conducted. Field research is basically as a validation of perceptions and responses, views, and strategies of supporting communities to preserve traditional arts. Field research was carried out in Prambon District, Nganjuk Regency, East Java Province. Research with this qualitative approach seeks to understand in depth and holistically a number of phenomena that are studied and not to test hypotheses proposed based on statistical formula models. To obtain this data, the research steps undertaken are observation, in-depth interviews, and focus group discussions (FGDs). Observations were made to describe the real picture in the field about the condition of traditional arts and attractions in the study location. While the interviews and FGDs were conducted with a number of informants to get a comprehensive picture of their perceptions and responses, views, attitudes, hopes for the existence of traditional arts. The informants

included community leaders, religious leaders, and other strategic figures.

\section{Discussion}

Traditional arts in East Java, especially in the Nganjuk Regency area, there are various kinds of arts that color the nation's culture. The diversity of types of art in East Java can add to the national treasury. Jaranan art is one of the arts that are popular in East Java, because almost every area in East Java has jaranan art. Nganjuk Regency is one of the districts that has jaranan art with its own characteristics compared to jaranan art in other areas, namely jaranan jarog (wayang orang) art.

Pogogan jaranan art first appeared in Sugihwaras Village, Prambon District, in 1956, precisely in Jimbir Hamlet, Sugihwaras Village, Prambon District, initiated by Mr. Maridjo (late) and Mr. Suparno (Sosro / Bambangan figures). Mr. Maridjo is an original artist from the Jimbir hamlet. Before 
establishing the network of pogogan, he was a tayak (panjak) artist of Tayub, Ludruk, Ketoprak, and Wayang Kulit, so that he did not experience any difficulties when he founded the association of jaranan. Mr. Maridjo has his own gamelan instrument so that it makes it easy to form a Pogogan network art group as it has developed in the surrounding area. Jaranan pogogan group or Jimbir pogogan was born in 1956 by the efforts of Mr. Maridjo with the group name "Teguh" which is in Javanese language which means durable urip, a name that means that the art of Jimbir pogogan jaranan remains alive at any time in line with the progress of time.

At the beginning of the staging of pogogan network in Jimbir Hamlet, Sugihwaras Village, Prambon Sub-district, Nganjuk Regency, in 1956, because at the time Jimbir hamlet had not yet been electrified because the staging of pogogan jarog was generally at night, for lighting using the c Made of cans or bottles used, cloth and kerosene, in addition to the Republic at the time for lighting also used once / torch lamps which are made of bamboo, cloth and kerosene or cooking oil. From the start, the pogogan network, namely in 1955 and 1956, received a positive response from the community, which was proven at the beginning of the performance by so many spectators who watched the art. This happened because at that time there were no entertainment facilities such as television or radio.

The development of Jaranan Pogogan's art especially in Prambon Sub-district experienced ups and downs. In the 1960s to 1970 the PKI issue developed which made people afraid to leave the house or even watch entertainment, because when the PKI issue was heated up in 1965, art was one of the ways for the PKI to seek shelter in the organization, namely LEKRA (People's Arts Institute) affiliated with the Communist Party. With this event, it greatly affected the joints of Indonesian people's lives, including art activists, because at that time the PKI used art as a medium to attract the masses to join as a PKI member, so that in the 1965 's period many arts art that did not dare to perform even some were disbanded for fear of being accused of being a member of the PKI.

The era of the 1970s was a glorious period of Pogogan jaranan art after experiencing a period of deterioration due to the events of G30S / PKI. Jarog Pogogan art "Teguh Rahayu" when its heyday had performed in various regions in East Java, namely Jember, Sepanjang, Surabaya, and Gresik. The Teguh Rahayu pogogan is almost every month in the period of 1968-1975, there are always invitations, both in circumcision, marriage, and village cleansing events. The 1977 period was a time when the network of pogogans declined, many other arts were increasingly developed and sought after by the public. These arts include ludruk, ketoprak, and campursari. Sentananewe jaranan art that developed in Tulungangung and Kediri also began to develop in Nganjuk Regency. In 1977 in the village of Sugihwaras began to be electrified so that the entertainment of electronic media such as radio and television began to be loved by the community.

Jaranan Pogogan "Teguh Rahayu" experienced a setback, namely in the end of 1979 and 1980, where the pogogan jar was rarely sought after by the public. There are several factors that influence the decline of Pogogan network art, in addition to declining public interest in Pogogan network art, namely the difficulty of getting a replacement (regeneration) from Pogogan network players, in addition to being difficult to learn, Pogogan players must have other skills besides dancing, namely communication skills, needing took almost 2 to 3 months to learn the Pogogan Jaranan dance movement because in every Pogogan jaranan movement has meaning and meaning. Pogogan fingers are plays with plays so there is dialogue in every game, not like monotonous fingers in general.

In addition to the difficult factor to regenerate players in Pogogan network, the decline in Pogogan network in Nganjuk district was also influenced by the development of Sentherewe jar / ndandi (trance) art. Jaranan ndadi began to develop in Nganjuk district in the 1980s. jaranan ndadi is a jaranan that develops in Tulungagung and Kediri, in its appearance jaranan ndadi displays a trance scene (ndadi). Jarandi Ndandi is more popular by the community than Pogogan Jarangan, because it is more attractive because it shows a possessed scene, so that young people at that time are more challenged to witness Jarandi Ndandi.

Although until now the network of pogogan still exists, but the players almost all of them are over 50 years old. Honors for bringing in pogogan networks today are around 13 million, because in addition to the older players, these players do not want to be given low wages because of the scarcity 
of pogogan jaranan art. This factor has made pogogan networks difficult to develop, because it requires funds that are expensive enough to bring pogogan networks. When compared to Nadiadi network which until now continues to grow and is popular with the public because to bring the art of Nadiadi network requires funds between 6 to 7 million. Jarog Pogogan is also less desirable in the education sector, because there are rarely schools in Nganjuk district that have extracurricular art in the Pogogan Jaranan. These factors have made pogogan networks in Nganjuk district difficult to develop and are unable to compete with other arts that still exist today.

\section{Conclusion}

Based on the data obtained by the author, it can be concluded from the formulation of the problem examined by the author about the Art of Jaranan Pogogan, Prambon District, Nganjuk Regency. Jaranan Pogogan or jaranan puppet art, people grew and developed as community entertainment at that time because at that time there was rarely community entertainment. At that time there was no entertainment such as television and radio, while other arts entertainment such as Wayang, Ketoprak rarely performed because of the high cost of responsiveness.

The development of Teguh Pogogan Teganan art, namely born in 1956 in Jimbir Hamlet, Sugihwaras Village, Prambon District. At the beginning of the staging the response of the people of Sugihwaras Village was so enthusiastic, it happened because at that time in the village of Sugihwaras it had not been electrified so that entertainment such as radio and television had not been felt by the community. 1965 was a difficult time for art activists in Indonesia, because at that time the PKI was a threat to the survival of the Indonesian people, including art activists and artists throughout Indonesia. The PKI used the arts as a tool to attract times so that it would become a follower and want to join as a member of the PKI.

\section{References}

Abdullah, Taufik et al. (1991). Metodologi Penelitian Agama, Sebuah Pengantar. Yogyakarta: PT. Tiara Wacana.

Ardianto, Arif. (1996). Kebudayaan dan Kesenian Jawa Timur. Sumenep: Widya Wacana Nusantara. Bagong Kussudiardja. (1992). Dari Klasik Hingga Kontemporer. Yogyakarta: Padepokan Press.

Baihaqi, Ahmad. (2001). Kesenian Tradisional Indonesia. Yogyakarta: Grafi Press.

Dinas Pendidikan dan Pariwisata Propinsi Jawa Timur. 2007. Program Pengembangan Kerjasama

Pengelolaan Kekayaan Budaya Museum Mpu Tantular. Surabaya: Dinas Pendidikan dan Kebudayaan Propinsi Jawa Timur.

Fadhilla, Nisa'u. (2013). Peran Dan Fungsi Paguyuban Wahyu Kridha Budhaya di Kota Kediri Jawa Timur. Apron Jurnal Pemikiran Seni Pertunjukan, 2 (1) 1-10

Kasdi, Aminuddin. (2001). Memahami Sejarah. Surabaya: Unesa University Press.

Kasdi, Aminuddin. (2014). Kaum Merah Menjarah, Aksi Sepihak PKI/BTI di Jawa Timur 19601965. Surabaya: Unesa University Press.

Kaulam, Salamanun. (2012). Simbolisme dalam Kesenian Jaranan Jaranan, Urna Jurnal Seni Rupa, 1

(2) $127-138$

Koentjaraningrat. (1989). Pengantar Ilmu Antropologi. Jakarta: Rineka Cipta.

Kuntowijoyo. (2003). Metodologi Sejarah. Yogyakarta: PT. Tiara Wacana Press.

Mulyono, Sri. (1983). Simbolisme dan Mistikisme Dalam Wayang. Jakarta: Gunung Agung.

Novia R, Riska. Bentuk. (2013). Penyajian Kesenian Jaranan Jawa di Desa Pakunden Kecamatan Pesantren Kota Kediri. Apron Jurnal Pemikiran Seni Pertunjukan, 2 (1) 11-21

Ndona, Y. (2019).Jawawawo Natural Monisms: Revelation Dimension of Peo and Inspiration for Faith-Dialogue in Multi Religious Society, Budapest International Research in Linguistics and Education Sciences (BirLE), P.74-84. 